\title{
Wound healing and silver nanoparticles
}

\author{
Hazem Mohammed Shaheen* \\ Professor, Department of Pharmacology and Therapeutics, Faculty of Veterinary Medicine, Damanhour University, Damanhour, El-Behera, Egypt
}

Burn injury induces global changes to the entire immune system resulting in suppressed immune function and increased susceptibility to infection. Patients with severe burns are more likely to die from sepsis due to the massive release of inflammatory mediators from the burn wounds [1]. The repair process of skin wound starts immediately during which various growth factors such as transforming growth factor beta (TGF- $\beta$ ) will release [2]. TGF- $\beta$ is the growth factor affecting all cell types that are involved in all stages of wound healing [3]. TGF- $\beta$ released by macrophages and platelets. It acts as a potent chemoattractant for macrophages, neutrophils, lymphocytes, and fibroblasts. TGF- $\beta$ stimulates release of other growth factors and induces its own auto expression. In addition, TGF- $\beta$ plays an important role in tissue fibrosis and post- injury scarring [4]. Abnormal levels of pro inflammatory mediators, such as tumor necrosis factor alpha (TNF $\alpha)$ interleukin-1b (IL-1b), interleukin-6 (IL-6), interleukin-8 (IL-8), and interleukin-10 (IL-10), have reported both systemically and locally in burn patient. A recent and interesting study indicates that genetically determined individual differences in IL-10 production might influence the susceptibility to septic complications in burned patients [5]. [6] showed that the circulating levels of the pro inflammatory cytokines, IL-6 and interferon-gamma (IFN- $\gamma$ ) were higher in rats with full thickness burns as compared to rats with only partial thickness burns, one hour after burn injury. The authors suggested that early elevation of IL- 6 and IFN- $\gamma$ ) can prolong inflammation in full-thickness burns. Interleukin 10 (IL-10) is a potent anti-inflammatory cytokine that plays a crucial, and often essential, role in preventing inflammatory and autoimmune pathologies $[7,8]$. Deficiency or aberrant expression of IL-10 can enhance inflammatory response to microbial challenge but also lead to development of inflammatory bowel disease and a number of autoimmune diseases [9,10]. For centuries, silver compounds and ions have extensively used for both hygienic and healing purposes, due to their strong bactericidal effects, as well as a broad-spectrum antimicrobial activity $[11,12]$. It seems that silver shows a multilevel antibacterial effect, due to blockage of respiratory enzyme pathways, alteration of microbial DNA and the cell wall [13]. Silver is applied to burns, either in the form of impregnated bandages or as a cream containing silver sulfadiazine as the active agent, considered the benchmark silver product [14]. The antimicrobial mechanism of AgNPs is generally considered as a multi-factor, multi-way, and multitarget process $[15,16,17]$. AgNPs can attach to the cell membranes and interact with the molecules on the membranes, which will damage the integrity and permeability of the membranes and thereby leading to the cytomorphosis and the leakage of intracellular contents $[18,19]$. And the reactive oxygen species (ROS) produced by AgNPs and silver ions released from AgNPs not only damage the cell membranes but also react with the molecules in the functional proteins and DNA, which will interfere the metabolism and DNA duplication [20,21]. AgNPs with more reactive facets had enhanced affinity with the cell membranes and increased dissolution rate of silver ions, which resulted in the enhanced antimicrobial activity [22,23,24]. The antimicrobial spectrum of AgNPs is broader than that of common antibiotics. Most researchers normally select Escherichia coli and Staphylococcus aureus to study the inhibition of bacteria by AgNPs $[25,26]$. The antibiotic ability of AgNPs against E. coli, Staphylococcus aurous, B. subtilis, and K. mobilis enhanced with increasing the silver content [27]. [28] studied the biocide activity of the AgNPs on Pseudomonas aeruginosa (a gram-negative bacterium), is an opportunistic microorganism that can cause severe, life-threatening infections. The bactericidal effect of AgNPs depends on different parameters including size, shape, and the surface charge of the particles. In this respect, smaller particles have greater antibacterial activity and shown to have two benefits. Firstly, they can easily reach the nuclear content of bacteria due to the structure of the bacterial cell wall, especially in gram-negative ones [29]. Secondly, they provide a greater surface area and therefore stronger bactericidal interactions [30,31]. NPs greater than $10 \mathrm{~nm}$ accumulate on the cellular surface and compromise cellular permeability; however, NPs smaller than $10 \mathrm{~nm}$ penetrate into the bacteria, affecting DNA and the enzymes leading to cellular death $[32,33]$. Furthermore, the electrostatic attraction between positively charged nanoparticles and negatively charged bacterial cells is shown to be another important aspect with regard to the antimicrobial activity of the AgNPs [19]. Although gram-positive and gram-negative bacteria have differences in their membrane structure, most of them have a negative charge. The gram-negative bacteria have a layer of lipopolysaccharide at the external surface followed by a thin layer of peptidoglycan. On the other hand, the cell wall in gram-positive bacteria is mainly composed of a thick layer of peptidoglycan [34]. Macrophages will infiltrate the wound tissue at approximately 3 days after neutrophils infiltration post-wounding, and be involved in the ongoing inflammatory process by performing phagocytosis of pathogens and necrotic cells or debris. They will release cytokines, chemokine and growth factors, such as IL4 , IL-1 $\beta$ and TNF- $\alpha$ to induce cell regeneration and tissue repair, as well as synthesis of collagen by fibroblasts and macrophages in healing tissue [35].

\section{References}

1. Meshulam-Derazon S, Nachumovsky S, Ad-El D, Sulkes J, Hauben DJ (2006) Prediction of morbidity and mortality on admission to a burn unit. Plast Reconstr Surg 118: 116-120. [Crossref]

2. Werner S, Grose R (2003) Regulation of wound healing by growth factors and cytokines. Physiol Rev 83: 835-870. [Crossref]

Correspondence to: Hazem Mohammed Shaheen, Professor, Department of Pharmacology and Therapeutics, Faculty of Veterinary Medicine, Damanhour University, Damanhour, El-Behera, Egypt, E-mail: dr_hazemshaheen3010@yahoo.com or hazem.shaheen@vetmed.dmu.edu.eg

Received: November 20, 2016; Accepted: December 11, 2016; Published: December 14, 2016 
3. Faler BJ, Macsata RA, Plummer D, Mishra L, Sidawy AN (2006) Transforming growth factor-beta and wound healing. Perspectives in Vascular Surgery and Endovascular Therapy 18: 55-62.

4. Nadworny PL, Wang J, Tredget EE, Burrell RE (2008) Anti-inflammatory activity of nanocrystalline silver in a porcine contact dermatitis model. Nanomedicine 4: 241-251. [Crossref]

5. Accardo Palumbo A, Forte GI, Pileri D, Vaccarino L, Conte F, D'Amelio L 2012 Analysis of IL-6, IL-10 and IL-17 genetic polymorphisms as risk factors for sepsis development in burned patients. Burns 38: 208-213. [Crossref]

6. Sakallioglu AE, Basaran O, Karakayali H, Ozdemir BH, Yucel M, Arat Z, et al. (2006) Interactions of systemic immune response and local wound healing in different burn depths: an experimental study on rats. J Burn Care Res 27: 357-366. [Crossref]

7. Kuhn R, Lohler J, Rennick D, Rajewsky K, Muller W (1993) Interleukin-10-deficient mice develop chronic enterocolitis. Cell 75: 263-274. [Crossref]

8. Sabat R, Grutz G, Warszawska K, Kirsch S, Witte E, Wolk K, et al. (2010) Biology of interleukin-10. Cytokine Growth Factor Rev 21: 331-344.

9. Gazzinelli RT, Wysocka M, Hieny S, Scharton-Kersten T, Cheever A, Kühn R, et al. (1996) In the absence of endogenous IL-10, mice acutely infected with Toxoplasma gondii succumb to a lethal immune response dependent on CD4+ $\mathrm{T}$ cells and accompanied by overproduction of IL-12, IFN-gamma and TNF-alpha. Journal of Immunology 157: 798-805. [Crossref]

10. Sellon RK, Tonkonogy S, Schultz M, Dieleman LA, Grenther W, Balish E, et al. (1998) Resident enteric bacteria are necessary for development of spontaneous colitis and immune system activation in interleukin-10-deficient mice. Infection and Immunity 66: 5224-5231. [Crossref]

11. Klasen HJ (2000) Historical review of the use of silver in the treatment of burns. I. Early uses. Burns 26: 117-130

12. Klasen HJ (2000) A historical review of the use of silver in the treatment of burns. II Renewed interest for silver. Burns 26: 131-138. [Crossref]

13. Melaiye A, Youngs JW (2005) Silver and its application as an antimicrobial agent. Expert Opin Ther Patents 15: 125-130.

14. Hussain S, Ferguson C (2006) Best evidence topic report. Silver sulphadiazine cream in burns. Emerg Med J 23: 929-932. [Crossref]

15. Bae E, Park HJ, Lee J, Kim Y, Yoon J, Park K, et al. (2010) Bacterial cytotoxicity of the silver nanoparticle related to physicochemical metrics and agglomeration properties. Environmental Toxicology and Chemistry / SETAC 29: 2154-2160.

16. Kahru A, Ivask A (2013) Mapping the dawn of nanoecotoxicological research. Acc Chem Res 46: 823-833. [Crossref]

17. Suresh AK, Pelletier DA, Doktycz MJ (2013) Relating nanomaterial properties and microbial toxicity. Nanoscale 5: 463-474. [crossref]

18. Jones MC, Hoek EM (2010) A review of the antibacterial effects of silver nanomaterials and potential implications for human health and the environment. Journal of Nanoparticle Research 12: 1531-1551.

19. Sondi I, Sondi SB (2004) Silver nanoparticles as antimicrobial agent: a case study on
E. coli as a model for Gram-negative bacteria. Journal of colloid and interface science 275: $177-182$

20. AshaRani PV, Mun G, Hande MP, Valiyaveettil S (2009) Cytotoxicity and genotoxicity of silver nanoparticles in human cells. ACS Nano 3: 279-290.

21. Hackenberg S, Scherzed A, Kessler M, Hummel S, Technau A, Froelich K, et al. (2011) Silver nanoparticles: evaluation of DNA damage, toxicity and functional impairment in human mesenchymal stem cells. Toxicology letters 201: 27-33.

22. Bansal V, Li V, O'Mullane AP, Bhargava SK (2010) Shape dependent electrocatalytic behaviour of silver nanoparticles. Crystengcomm 12: 4280-4286.

23. Andrade RM, Cho AT, Hu PG, Lee SJ, Deming CP, Sweeney SW, et al. (2015) Enhanced antimicrobial activity with faceted silver nanostructures. J Mater Sci 50: 2849-2858.

24. Vukoje I, Lazic V, Vodnik V, Mitric M, Jokic B, Ahrenkiel SP, et al. (2014) The influence of triangular silver nanoplates on antimicrobial activity and color of cotton fabrics pretreated with chitosan. J Mater Sci 49: 4453-4460.

25. Lee BU, Yun SH, Ji JH, Bae GN (2008) Inactivation of S. epidermidis, B. subtilis, and E. coli bacteria bioaerosols deposited on a filter utilizing airborne silver nanoparticles. Journal of microbiology and biotechnology 18: 176-182.

26. Paula MMD, Franco CV, Baldin MC, Silva (2009) Synthesis, characterization and antibacterial activity studies of poly-\{styrene-acrylic acid\} with silver nanoparticles. Materials Science and Engineering 29: 647-650.

27. Zhang Y, Peng H, Huang W, Zhou Y, Yan D (2008) Facile preparation and characterization of highly antimicrobial colloid $\mathrm{Ag}$ or $\mathrm{Au}$ nanoparticles. $J$ Colloid Interface Sci 325: 371-376. [crossref]

28. Flores CY, Diaz C, Rubert A, Benitez GA, Moreno MS, Lorenzo M, et al. (2010) Spontaneous adsorption of silver nanoparticles on $\mathrm{Ti} / \mathrm{TiO} 2$ surfaces. Antibacterial effect on Pseudomonas aeruginosa. Journal of colloid and interface science 350: 402-408.

29. Thiel J, Pakstis L, Buzby S, Raffi M, Ni C, et al. (2007) Antibacterial properties of silver-doped titania. Small 3: 799-803. [crossref]

30. Castanon M, Martinez NN, Gutierrez MF, Mendoza MJ (2008) Synthesis and antibacterial activity of silver nanoparticles with different sizes. $J$ Nanopart Res 10 : $1343-1348$

31. Pal S, Tak YK, Song JM (2007) Does the antibacterial activity of silver nanoparticles depend on the shape of the nanoparticle? A study of the Gram-negative bacterium Escherichia coli. Applied and environmental microbiology 73: 1712-1720.

32. Inphonlek S, Pimpha N, Sunintaboon P (2010) Synthesis of poly (methyl methacrylate) core/chitosan-mixed-polyethyleneimine shell nanoparticles and their antibacteria property. Colloids Surf B Biointerfaces 77: 219-226.

33. Xiu ZM, Zhang QB, Puppala HL, Colvin VL, Alvarez PJ (2012) Negligible particlespecific antibacterial activity of silver nanoparticles. Nano letters 12: 4271-4275.

34. Baron S, Fons M, Albrecht T (1996) Viral Pathogenesis. Medical Microbiology. 4th edition. University of Texas Medical Branch at Galveston, USA [crossref]

35. Morales GJ, Ariganello MB, Hammami I, Thibault M, Jolicoeur M, et al. (2011) Biodegradable chitosan particles induce chemokine release and negligible arginase-1 activity compared to IL-4 in murine bone marrow-derived macrophages. Biochem Biophys Res Commun 405: 538-544.

Copyright: (C2016 Shaheen HM. This is an open-access article distributed under the terms of the Creative Commons Attribution License, which permits unrestricted use, distribution, and reproduction in any medium, provided the original author and source are credited. 